\title{
RUNX1/SH3D19 Fusion Protein
}

National Cancer Institute

\section{Source}

National Cancer Institute. RUNX1/SH3D19 Fusion Protein. NCI Thesaurus. Code C99302.

A fusion protein encoded by the RUNX1/SH3D19 fusion gene. This protein is comprised of part of the $\mathrm{N}$-terminal runt domain of the runt-related transcription factor 1 protein fused to the entire SH3 domain-containing protein 19. 